\title{
The influence of operating cash flow and investment cash flow to the
}

\section{accounting conservatism measurement*}

\author{
Dwi Martani, Narita Dini \\ (Departement of Accounting, Faculty of Economics, University of Indonesia, Depok 16424, Indonesia)
}

\begin{abstract}
This research investigates the influence of cash flow from operating and investing activities to conservative accounting practices. Cash flow from operating activities shows the performance of a firms and its earnings quality. Higher operating cash flow indicates better performance, and it is expected to produce better earnings in the future. Better earnings would be a positive signal for investor as a basic to predict the firm's prospect. Investing activities will push or lowering operating assets. For firms that implementing the conservative accounting practices, changes in investment will influence the earnings' quality. When the investment goes up, the conservative practices will cause lower reported earnings. The hypothesis for this research is that there is a positive relation between operating and investing cash flow to accounting conservatism practices about whether it uses market value or accrual measurement. The result of the first test using market value accounting conservatism as a proxy has shown a positive relation between operating and investing activities cash flow to accounting conservatism practices, but investing cash flow does not have a significant effect to accounting conservatism practices. The result from the second test, using accrual measurement accounting conservatism has shown a significant positive relation for both operating and investing cash flow to accounting conservatism practices. A positive relation between operating and investing cash flow to accounting conservatism practices indicates that accounting conservatism is one of the tools that can be used to measure firm's financial performance and as an investment decision making tool for investor. Nevertheless those effects highly depend on the accounting conservatism proxy measurement used.
\end{abstract}

Key words: accounting conservatism; operating cash flow; investing cash flow

\section{Introduction}

Accounting conservatism is traditionally defined as the accounting guideline that understates assets and revenues and overstates liabilities and expenses (Hendriksen \& Van Breda, 1992). Expenses should be recognized earlier than later while revenue should be recognized later than sooner. Thus, net income will result in a lower figure. Furthermore, conservatism holds that in financial report, it is preferable to be pessimistic than optimistic since there is less chance of financial readers being hurt by relying on prepared financial statements. It is also argued that pessimism is needed to counteract the optimism of management. However, excess conservatism may result in misguided decisions.

Despite criticism from many quarters, including standard-setters, conservatism appears not only to have survived in accounting for many centuries, but also to have increased in the recent years. Previous researches have

\footnotetext{
* This paper is part of Narita's thesis in post graduate program in Finance, FEUI, and Dwi Martani is a supervisor.

Dwi Martani, Ph.D., lecturer, Departement of Accounting, Faculty of Economics, University of Indonesia; research field: accounting.

Narita Dini, Master, Departement of Accounting, Faculty of Economics, University of Indonesia; research fields: accounting and finance.
} 
been done to test the accounting conservatism such as conflicting in dividend policy (Ahmed, Billings, Morton \& Stanford-Harris, 2002), lowering the litigation and contract fee (Holthausen \& Watts, 2001), corporate governance and ownership structure (Ball, Kothari \& Robin, 2000) and auditor responsibility (Basu, 1997). In Indonesia, the investigation has been done to support the hypothesis saying that the rate of conservatism applied in a firm linearly effects on its market value (Mayangsari, Sekar \& Wilopo, 2002).

This research has been put attention on the influence of firm cash flow as one of the financial performance to the accounting conservatism. Cash flow report provides the information on the amount of cash a firm generates from the revenues, excluding costs associated with long-term investment on capital items or investment in securities. It is comparable to the accrual information on profit-loss report. The firm's profit and cash flow are closely observed by the investors.

Many researches have been done to determine the influence of cash flow report to the accounting conservatism from different point of views. Some of those views are firm market value and accounting data which is related to the cash flow operation (Feltham \& Ohlson, 1995), influence of investing to the quality of firm's profit when they apply the accounting conservatism principle (Penman \& ZHANG, 2002), and influence of the change in cash investments and the change in lagged operating assets to the regression of returns on earnings levels and earnings changes when applying accounting conservatism principle (Easton \& Pae, 2004).

After reviewing the accounting conservatism role on the cash flow reports of companies in Indonesia, a further research has been done by the author to study the influence of operating cash flow and investment with additional variables that are leverage, profitability, sales growth and firm size to the accounting conservatism level. This level is measured with two measurements, which are market value (Beaver \& Ryan, 2000) and accrual measurement (Givoly \& Hayn, 2000). The scope of the research is focused on the source of funds from firm operation, which is used to the investment.

\section{Research methodology}

The research samples were all firms, listed in Indonesian Stock Exchange (Bursa Efek Indonesia) from 2000-2006. They were taken using purposive sampling method. The financial performance data of each firm was taken from their balance of payment, profit loss and cash flow reports.

Table 1 Abbreviations

\begin{tabular}{|l|l|}
\hline CONMKT & Accounting conservatism with market value measurement \\
\hline CONACC & Accounting conservatism with accrual measurement \\
\hline CFO & Operating cast flow \\
\hline CFI & Investment cast flow \\
\hline LEV & Leverage \\
\hline ROA & Probability \\
\hline NPM & Net profit margin \\
\hline ROE & Return on equity \\
\hline SALESGROWTH & Sales growth \\
\hline SIZE & Firm size \\
\hline
\end{tabular}

In order to verify the effect of independent variables on the dependent variables, data was analysed statistically using multiple linear regression analysis by employing EVIEWS 5.1 software. The ordinary least square (OLS) was applied to do the estimation technique. Furthermore, cross section weight and robust test were prepared using STATA 8 
software in order to avoid the heteroscedasticity. Other statistic tests to bring the best linier unbiased estimator (BLUE assumption) were as follows: multicollinearity, autocorrelation, goodness of fit $t$ test, $F$ test and $R^{2}$ test.

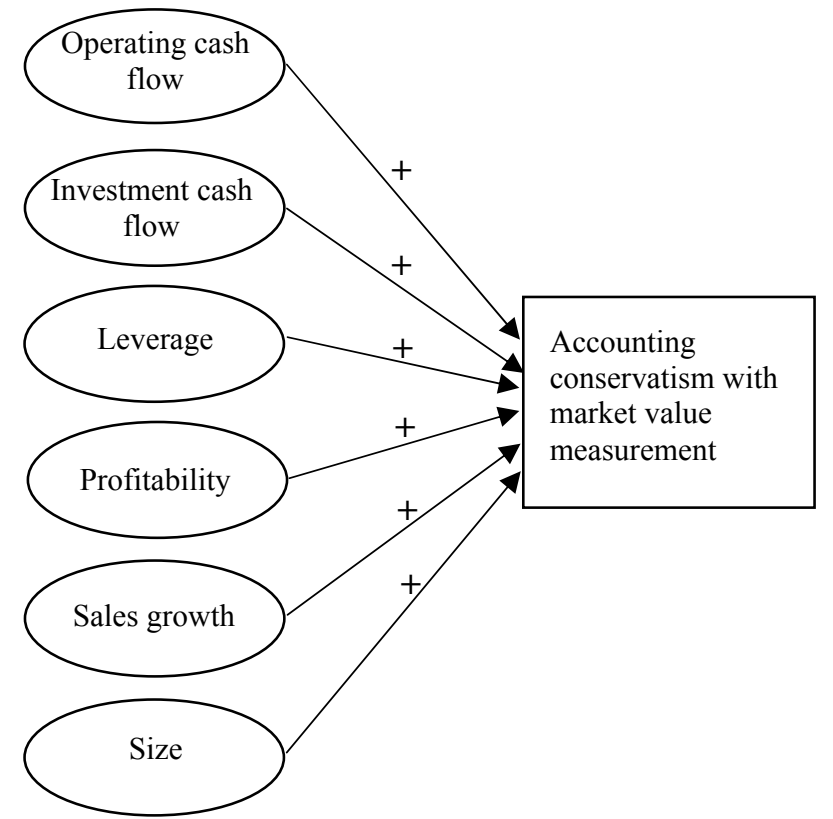

Fig. 1 Model 1: Accounting conservatism with market value measurement

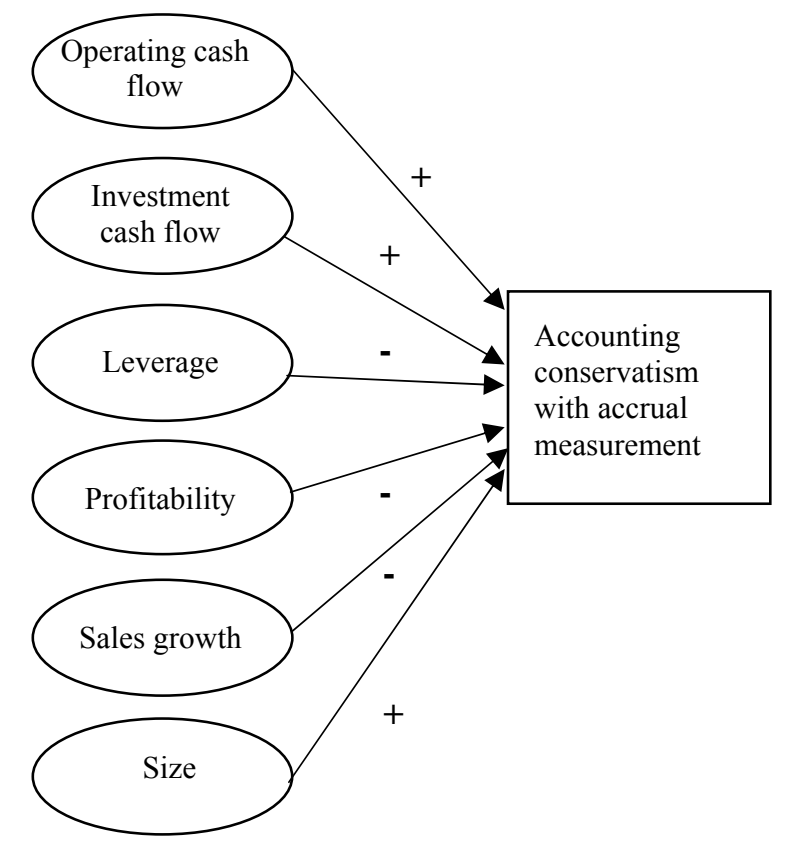

Fig. 2 Model 2: Accounting conservatism with accrual measurement

Empirical model equations, which were used in this research, are as follows:

Model 1: Accounting conservatism with market value measurement:

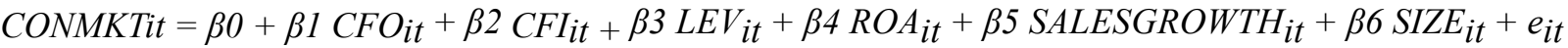

Model 2: Accounting conservatism with accrual measurement:

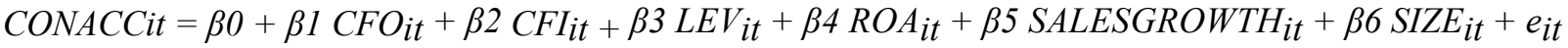


The abbreviations of the variables are showed in Table 1.

The research framework charts for model 1 and model 2 are shown in Fig. 1 and Fig. 2 consecutively.

As depicted in Fig. 1, all used variables were predicted to have a linear relation on the accounting conservatism with market value measurement. While Fig. 2 assumed that some variables, for example, profitability, sales growth and firm size have an inverse relation on the accounting conservatism with accrual measurement.

\section{Results and discussion}

Table 2 summarizes the descriptive statistic of all samples for model 1 and model 2. It can be seen from Table 2 that the CONACC and CONMKT variables had average values of -0.020 and 1.16E-07 respectively. These average values are close to zero, therefore the number of firms applying accounting conservatism were still low.

Operating cash flow and investment cash flow had average values of 0.118 and -0.072 . This indicated that the firm's operating cash flow was used for funding the investment.

The model 1 test results are listed in Table 3. It is shown in Table 3 that the adjusted $R^{2}$ value of 0.12 verified that $12 \%$ of the accounting conservatism with market value measurement could be explained by model's independent variables. While the $F$ Test value of less than $1 \%$ indicated that the all model's independent variables had significant influence to the dependent variables. Furthermore, the BLUE assumption test has shown that the model did not demonstrate heteroscedasticity and multicollinearity.

The $t$ test showed that the CFO, LEV and SIZE had positive effects on the accounting conservatism with market value measurement, and each of those variables had the significance level on 5\%. While the SALES GROWTH with the level on $1 \%$ indicated the contrary effect.

Table 2 Descriptive statistic of sample population for model 1 and model 2

\begin{tabular}{llcccc}
\hline \multicolumn{1}{c}{ Variable } & Obs & Mean & Std. Dev. & Min & Max \\
\hline CONACC & 126 & -0.020 & 0.063 & -0.308 & 0.123 \\
CONMKT & 126 & $1.16 \mathrm{E}-07$ & 0.731 & -2.407 & 0.742 \\
CFO & 126 & 0.118 & 0.078 & -0.105 & 0.381 \\
CFI & 126 & -0.072 & 0.110 & -0.908 & 0.134 \\
LEV & 123 & 0.004 & 0.291 & -0.929 & 0.822 \\
ROA & 126 & 0.076 & 0.118 & -1.017 & 0.278 \\
SALES GROWTH & 126 & 0.014 & 1.615 & -3.516 & 4.719 \\
SIZE & 126 & 29.250 & 1.309 & 26.500 & 31.690 \\
\hline
\end{tabular}

The operating cash flow (CFO) variable with the coefficient of 1.88 indicated that the increase of current operating cash flow would be followed by future profit rising prospect. Therefore the investor's expectation on the firm's market value would be growing as well. This finding is aligned with the hypothesis and the previous research (Easton \& Pae, 2004; Beaver \& Ryan, 2000).

The investment cash flow (CFI) did not have the significant effect on the accounting conservatism with market value measurement. This might be resulted by the diverged condition of stock market and the sample characteristics in Indonesia. In addition, the length of the research might also affect the result.

The variable of leverage (LEV) with coefficient of 0.26 indicated that the rising of firm debt level would induce the bondholder to choose the conservatism practise to protect their interests in paying the debts. 
Table 3 Model 1: Accounting conservatism with market value measurement test results

\begin{tabular}{|c|c|c|c|c|}
\hline \multicolumn{5}{|c|}{$\mathrm{CONMKT}_{\text {it }}=\beta 0+\beta 1 \mathrm{CFO}_{\mathrm{it}}+\beta 2 \mathrm{CFI}_{\mathrm{it}}+\beta 3 \mathrm{LEV}_{\mathrm{it}}+\beta 4 \mathrm{ROA}_{\mathrm{it}}+\beta 5 \mathrm{SALESGROWTH}_{\mathrm{it}}+\beta 6 \mathrm{SIZE}_{\mathrm{it}}+\mathrm{e}_{\mathrm{it}}$} \\
\hline \multicolumn{5}{|c|}{ Dependent variabel : CONMKT } \\
\hline Independent Variable & Sign Expectation & Coefficient & t-Stat & Significance \\
\hline Constant & $?$ & -3.36 & -3.187610 & 0.0018 \\
\hline $\mathrm{CFO}$ & + & 1.88 & 2.159612 & $* * 0.0329$ \\
\hline CFI & + & 0.56 & 0.929808 & 0.3544 \\
\hline LEV & + & 0.26 & 1.682304 & $* * * 0.0952$ \\
\hline ROA & + & 0.19 & 0.401651 & 0.6887 \\
\hline SALES GROWTH & + & -0.17 & -3.834916 & $* 0.0002$ \\
\hline SIZE & + & 0.10 & 3.045364 & $* 0.0029$ \\
\hline \multicolumn{4}{|l|}{ Prob (F-stat) } & 0.001642 \\
\hline \multicolumn{4}{|l|}{$\operatorname{Adj} R^{2}$} & 0.121793 \\
\hline
\end{tabular}

Notes: * Significance level 1\%; *** Significance level 5\%; **** Significance level 10\%.

The profitability (ROA) variable and its substitute: Net profit margin (NPM) and return on equity (ROE) did not show any significant effect on the accounting conservatism with market value measurement.

The firm sales growth (SALES GROWTH) variable with coefficient of -0.17 was inconsistent with the hypothesis and pervious research (Ahmed, Billings, Morton \& Stanford-Harris, 2002). This negative effect could be explained through the realisation of asset growth with the book to market ratio. There would be a disparity between old and new asset if the growth of selling and the buying of new asset increase. Therefore, the book value and market value of new assets would not be significantly different. Consequently, the application of conservatism with market value measurement would be lower.

The model of firm size variable (SIZE) indicated that a firm most likely to apply the accounting conservatism with market value measurement as its size grows.

The second model simulation results of accounting conservatism with accrual measurement are shown in Table 4. As can be seen from Table 4, the $t$ test of CFO, CFI and LEV variables showed the positive effect toward the accounting conservatism with accrual measurement. While the other variables, namely ROA and SIZE indicated the opposing effects on the conservatism.

Table 4 Model 2: Accounting conservatism with accrual test measurement results

\begin{tabular}{|c|c|c|c|c|}
\hline \multicolumn{5}{|c|}{$\mathrm{CONACC}_{\text {it }}=\beta 0+\beta 1 \mathrm{CFO}_{i t}+\beta 2 \mathrm{CFI}_{\text {it }}+\beta 3 \mathrm{LEV}_{\text {it }}+\beta 4 \mathrm{ROA}_{\mathrm{it}}+\beta 5 \mathrm{SALESGROWTH}_{\text {it }}+\beta 6 \mathrm{SIZE}_{\text {it }}+\mathrm{e}_{\mathrm{it}}$} \\
\hline \multicolumn{5}{|c|}{ Dependent variabel: CONACC } \\
\hline Independent variable & Sign expectation & Coefficient & $t$-Stat & Significance \\
\hline Constant & $?$ & 0.404918 & 2.78047 & 0.00630 \\
\hline $\mathrm{CFO}$ & + & 0.275605 & 2.975981 & $* 0.00360$ \\
\hline CFI & + & 0.092784 & 2.909132 & $* 0.00430$ \\
\hline LEV & + & 0.082985 & 4.562475 & $* 0.00000$ \\
\hline $\mathrm{ROA}$ & - & -0.247974 & -3.005075 & $* 0.00330$ \\
\hline SALES GROWTH & - & 0.003206 & 0.970288 & 0.33390 \\
\hline SIZE & + & -0.014818 & -2.961717 & $* 0.00370$ \\
\hline \multicolumn{4}{|l|}{ Prob $(F$-stat $)$} & 0.000000 \\
\hline \multicolumn{4}{|l|}{$\operatorname{Adj} R^{2}$} & 0.342186 \\
\hline
\end{tabular}

Note: * Significance level $1 \%$.

The operating cash flow (CFO) variable with coefficient value of 0.27 suggested that the increase of 
operating cash flow would lower accrual value. Therefore, the firm becomes more conservatism.

The investment cash flow (CFI) coefficient value of 0.09 showed that the increase of investment cash flow would generate the firm to invest in NPV positive projects. As a consequence, the firm's profit recognition would be delayed. This delay would induce the growth of accounting conservatism with accrual measurement.

The leverage (LEV) variable with coefficient of 0.08 indicated that the growth of firm debt level would lower the accrual value thus, increasing the accounting conservatism with accrual measurement.

Despite having positive sign, the sales growth (SALES GROWTH) variable did not have significant effect on the accounting conservatism with accrual measurement. This discrepancy might be because of the firm selling variation which was not based on its industry and the few numbers of observed samples.

The model of profitability (ROA) and firm size (SIZE) showed the negative sign of -0.24 and -0.01 respectively. The result of the SIZE variable model was not match with the hypothesis. This because in Indonesia, the small firm usually has conservative financial report in order to avoid the higher political cost.

\section{Conclusions}

(1) Cash flow report has a significant role in verifying the firm ability to fulfil their operating necessity. In relation to credit incentive, the bank requires detail information on cash flow to assess the firm ability in interest repayment.

(2) The operating cash flow (CFO) has a substantially positive influence on the accounting conservatism with market value measurement.

(3) Despite having positive sign, the investment cast flow (CFI) does not have a significant effect on the accounting conservatism with market value measurement.

(4) Both, CFO and CFI have an important impact on the accounting conservatism with accrual measurement.

(5) By applying two different conservatism measurements, namely, market value and accrual measurements, it is found that the influence of financial cash flow on the level of conservatism depends on the applied of its measurement.

\section{References:}

Ahmed, A. S., Billings, B. K., Morton, R. M. \& Stanford-Harris, M.. (2002). The role of accounting conservatism in mitigating bondholders-shareholders conflicts over dividend policy and in reducing debt costs. The Accounting Review, 77, 867-890.

Ball, R., Kothari, S. P. \& Robin, A.. (2000). The effect of international institutional factors on properties of accounting earnings. Journal of Accounting and Economics, 29 (February), 1-51.

Basu, S.. (1997). The conservatism principle and the asymmetric timeliness of earnings. Journal of Accounting and Economics, 24, 3-38.

Beaver, W. H. \& Ryan, S. G. (2000). Biases and lags in book value and their effects on the ability of the book-to-market to predict book return on equity. Journal of Accounting Research, 38, 127-148.

Easton, P. \& Pae, J.. (2004). Accounting conservatism and relation between returns and accounting data. Review of Accounting Studies, 9, 495-521.

Feltham, G. E. \& Ohlson, J. A.. (1995). Valuation and clean surplus accounting for operating and financial activities. Contemporary Accounting Research, 11, 689-731.

Givoly, D. \& Hayn, C.. (2000). The changing time-series properties of earnings, cash flow and accruals: Has financial reporting become more conservative? Journal of Accounting and Economics, 29, 287-320.

Hendriksen, E. \& Van Breda, M.. (1992). Accounting theory (5th ed.). Homewood, IL: Irwin.

Holthausen, R. W. \& Watts, R. L.. (2001). The relevance of value relevance literature for financial accounting standard setting. Journal of Accounting and Economics, 3, 305-360.

Mayangsari, Sekar \& Wilopo. (2002). Accounting conservatism, value relevance and discretionary accruals: Implications for empirical model-Ohlson Feltham. (1996). Journal of Accounting Research Indonesia, 5(3), 291-310. (in Indonesian)

Penman, S. H. \& ZHANG, X.. (2002). Accounting conservatism, the quality of earnings and stock returns. The Accounting Review, $77(2), 237-264$.

(Edited by Ruby and Chris) 